\title{
Pristimerin Inhibits Inducible Nitric Oxide Synthase Expression Induced by TLR Agonists
}

\author{
Su-Yeon Kim*, Sung-Hye Heo ${ }^{*}$, Sin-Aye Park ${ }^{* *}$ and Hyung-Sun Youn ${ }^{\dagger, * *}$ \\ Department of Biomedical Laboratory Science, College of Medical Sciences, \\ SoonChunHyang University, Chungnam, Asan 31538, Korea
}

Toll-like receptors (TLRs) are one of the families of pattern recognition receptors (PRR) operating in the innate immunity. TLRs have the ability to recognize relatively conserved microbial components, which are generally referred to as pathogenassociated molecular patterns (PAMPs). The activation of TLRs signaling leads to the activation of NF- $\kappa \mathrm{B}$ and the expression of pro-inflammatory gene products such as cytokines and inducible nitric oxide synthase (iNOS). To evaluate the therapeutic potential of pristimerin, which is a naturally occurring triterpenoid compound from Celastraceae plants, iNOS expression induced by MALP-2 (TLR2 and TLR6 agonist), Poly[I:C] (TLR3 agonist), or LPS (TLR4 agonist) were examined. Pristimerin suppressed the iNOS expression induced by MALP-2, Poly[I:C], or LPS. These results suggest that pristimerin can modulate TLRs signaling pathways leading to decreased inflammatory gene expression.

Key Words: Pristimerin; Inducible nitric oxide synthase; TLR; Inflammation; LPS

\section{서 론}

미생물 감염, 조직 손상 등과 같은 외부 자극에 반응하 여 유도되는 만성염증(chronic inflammation)은 여러 질환의 발병과 관계 있는 것으로 알려져 있다(Ferrero-Miliani et al., 2007). 이러한 염증은 병태생리학(pathophysiology)적 인 현상으로, inducible nitric oxide synthase (iNOS) 효소가 염증 유발에 중요한 기능을 하는 것으로 보고되어 있다 (Murakami and Ohigashi, 2007). 산화질소(NO)는 기체 상태 의 간단한 무기 분자로, 세포 내에서 전달자의 기능을 가 지고 있다. 포유류의 경우 $\mathrm{NO}$ 는 $\mathrm{NOS}$ 라고 불리는 효소군 에 의해 합성되며, NO 합성은 NOS1(neuronal 또는 nNOS), NOS2(endothelial 또는 eNOS), 그리고 NOS3(inducible 또는 $\mathrm{iNOS}$ )의 세 가지 이성질체 효소 중 하나에 의해서 촉매화
된다(Knowles, 1996). iNOS는 아미노산 L-arginine에서 질소 산화물(NO)을 생성하는 데 중요한 세 가지 핵심 효소 중 하나이다. $\mathrm{iNOS}$ 는 다양한 생리학적 조건(혈압 조절, 상처 치유, 호스트 방어 메커니즘 등)과 병리생리학(염증, 감염, 신가소성 질환, 간경화증, 당뇨병 등)에서 중요한 역할을 담당한다(Lechner et al., 2005). iNOS는 nitric oxide (NO)를 생성하고, 생성된 $\mathrm{NO}$ 는 세포 독성 효과가 있어 이와 관련 된 염증 및 질병을 유도하는 것으로 알려져 있다(Vallance, 2003).

Toll-like receptors (TLRs)는 병원체 인식 수용체로서 세 균, 바이러스, 진균 및 기생충과 같은 병원균의 침입에 의 한 염증반응에서 중요한 역할을 한다(Kawai and Akira, 2010). 포유류 세포에서 최소 13 개의 TLRs가 발견되었으며, 이것은 박테리아, 바이러스 등을 포함한 다양한 pathogenassociated molecular patterns (PAMPs)을 인식한다(Kawai and

Received: January 14, 2019 / Accepted: March 14, 2019

*Ungraduate student, ${ }^{* *}$ Professor.

†Corresponding author: Hyung-Sun Youn. Department of Biomedical Laboratory Science, College of Medical Sciences, Soonchunhyang University, Soonchunhyang-Ro 22, Shinchang-Myun, Asan-Si, Chungnam 31538, Korea. Tel: +82-41-530-3086, Fax: +82-41-530-3085, e-mail: hyoun@sch.ac.kr (C)The Korean Society for Biomedical Laboratory Sciences. All rights reserved.

(c) This is an Open Access article distributed under the terms of the Creative Commons Attribution Non-Commercial License (http://creativecommons.org/licenses/by-nc/3.0/) which permits unrestricted non-commercial use, distribution, and reproduction in any medium, provided the original work is properly cited. 
Akira, 2010; Youn, 2012). TLRs가 자극을 인식하면 동종이 합체를 형성하여 어댑터 분자(adaptor molecule)인 myeloid differential factor 88 (MyD88) 또는 TIR domain-containing adaptor inducing interferon- $\beta$ (TRIF)를 유도하고, 마침내 전 사인자 NF- $\mathrm{NB}$ 나 interferon regulatory factor 3 (IRF3)의 활성 을 증가시킨다(Kawai and Akira, 2010). 이러한 전사인자의 활성화는 cytokine, $\mathrm{iNOS}$ 와 같은 염증 관련 유전자의 발현 을 증가시키고 결국 여러 질병을 초래하게 된다(Akira and Takeda, 2004). 또한 TLRs 신호전달 시스템의 비정상적인 작용은 많은 만성염증 질환과 관련이 있는 것으로 알려져 있다. 그러므로 TLRs의 신호전달 시스템을 효과적으로 조절한다면 여러 병원균들로부터 유도되는 염증반응이나 그에 따른 다양한 질병들을 예방할 수 있을 것이라 기대 된다.

Pristimerin (Fig. 1A)은 미역취 나무(Goldenrod), 태산목 (Magnolia grandiflora) 등에서 추출되는 천연물질로서, triterpenoid 구조를 가지고 있다. Pristimerin은 항산화, 항우울증, 항박테리아, 항염, 그리고 항암작용을 포함한 여러 가지 약리학적 효능을 가지고 있는 것으로 알려져 있다(Costa et al., 2008; Tong et al., 2014). 하지만 이러한 pristimerin의 약리학적 효능에 대한 분자적 작용기전은 아직까지 완전 히 밝혀져 있지 않다. 그러므로 본 연구에서는 pristimerin 이 TLRs 신호전달 시스템을 조절함으로써 iNOS를 포함 한 염증반응에 미치는 영향에 대해 알아보고자 한다.

\section{재료 및 방법}

재료

실험에 사용한 MALP-2 (macrophage-activating lipopeptide of $2 \mathrm{kDa}$ ), LPS (lipopolysaccharide), Polyriboinosinic polyribocytidylic acid (poly[I:C])는 Alexis Biochemical (San Diego, CA, USA), List Biological Lab (San Jose, CA, USA), Amersham Biosciences (Piscataway, NJ, USA)로부터 각각 구입하였다. $\mathrm{iNOS}$ 와 $\beta$-actin 항체는 BD Biosciences (San Jose, CA, USA) 와 Santa Cruz Biotechnology (Santa Cruz, CA, USA)로부터 각각 구입하였다. Pristimerin과 그 밖의 다른 시약들은 Sigma-Aldrich로부터 구입하였다.

\section{세포 배양}

RAW264.7 세포들은(murine monocytic cells, ATCC TIB-71) 10\% (v/v) FBS, 100 units/mL Penicillin, $100 \mu \mathrm{g} / \mathrm{mL}$ streptomycin 이 포함된 Dulbecco's modified Eagle's medium (DMEM)을
사용하여, $5 \% \mathrm{CO}_{2} / \mathrm{air}, 37^{\circ} \mathrm{C}$ 에서 배양하였다.

\section{Plasmid}

iNOS-luciferase plasmid는 Daniel Hwang (University of California, Davis, CA, USA)으로부터 제공받았으며, Heat shock protein (HSP) 70- $\beta$-galactosidase plasmid는 R. Modlin (University of California, Los Angeles, CA, USA)으로부터 제공받았다. 위의 모든 DNA는 EndoFree Plasmid Maxi kit (Qiagen, Valencia, CA, USA)을 사용하여 준비되었다.

\section{Cell viability test}

세포 생존율은 3-(4,5-dimethylthiazol-2-yl)-5(3 carboxymethoxyphenyl)-2-(4-sulfophenyl)-2H-tetrazolium (MTT) 사용 하여 측정되었다. 세포를 96 well plate에 분주하고 일정 시 간 약물을 처리한 후, well plate에 CellTiter 96 AQueous One Solution Reagent (Promega, Madison, WI, USA)를 첨가하였 으며, 4시간 동안 배양하였다. 그 후 96 well plate reader를 사용하여 $490 \mathrm{~nm}$ 에서 흡광도를 측정하였다.

\section{Transfection과 luciferase를 이용한 유전자발현 분석 (luciferase reporter gene assay)}

INOS 유전자의 발현은 transfection 방법을 사용하여 분 석하였다(Youn et al., 2005; Youn et al., 2006c). RAW264.7 세 포를 well plates에 균등 분주하였고, overnight 후 50 60\% 정도의 증식을 보일 때, iNOS-luciferase plasmid와 HSP70$\beta$-galactosidase plasmid는 Superfect transfection 시약(Qiagen, Valencia, CA, USA)을 사용하여 세포 안으로 transfection 시 켰다. Luciferase assay system (Promega, Madison, WI, USA)을 사용하여 luciferase의 활성을 측정하였으며, $\beta$-galactosidase 의 활성화 정도를 확인하여 표준화시켰다.

\section{Immunoblotting}

세포로부터 추출된 단백질들은 SDS-PAGE (sodium dodecyl sulfate-polyacrylamide gel electrophoresis)에서 크기 에 따라 분리되었으며, 이후 polyvinylidene difluoride membrane으로 이동되었다(Youn et al., 2006a; Youn et al., 2006b). Membrane은 $0.1 \%$ Tween 20와 5\% 탈지 건조된 우유를 포 함하고 있는 phosphate-buffered saline에서 blocking을 하였 으며, 측정하고자 하는 단백질의 1차 항체를 붙이고 horseradish peroxidase가 결합된 2차 항체를 붙인 후, $\mathrm{iNtRON}$ western blot detection system (Seongnam, Gyeonggi-do, Korea) 을 사용하여 단백질의 발현을 확인하였다. 

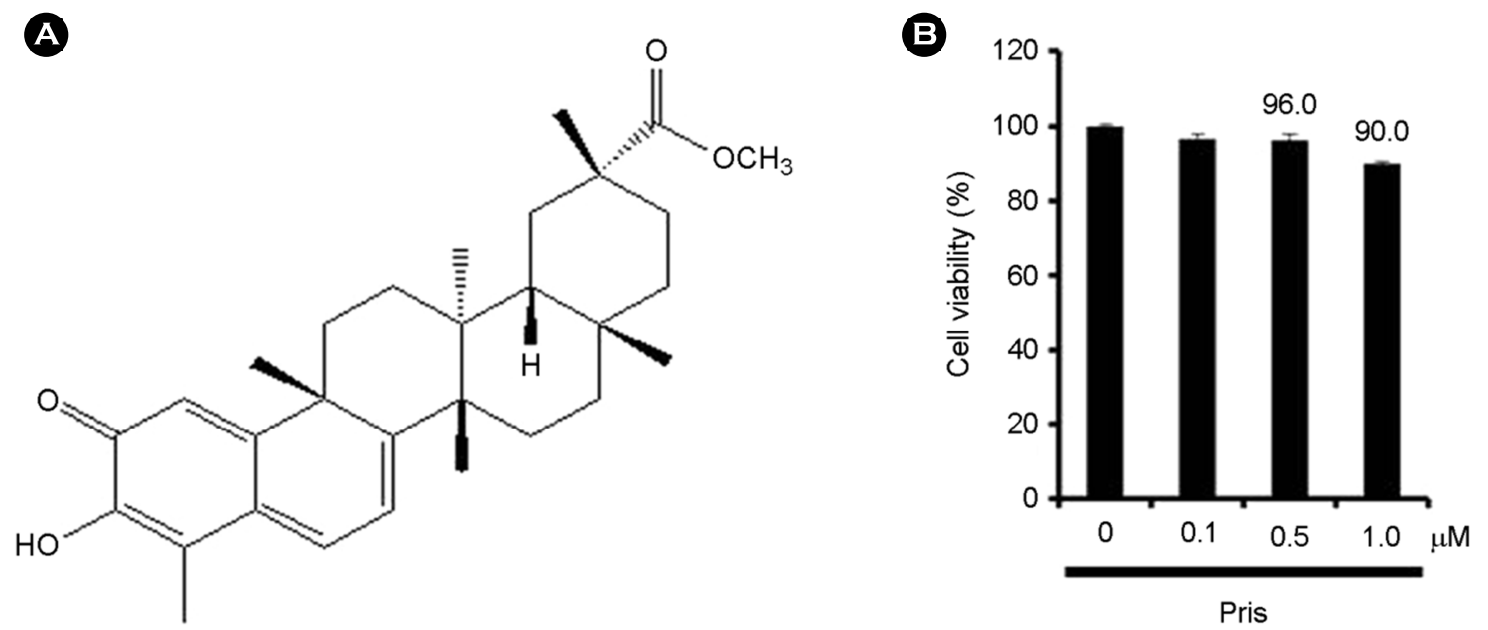

Fig. 1. (A) The structure of pristimerin. (B) RAW264.7 cells were treated with pristimerin $(0.1,0.5 .1 .0 \mu \mathrm{M})$ for $4 \mathrm{~h}$. Twenty microliters of the CellTiter $96 \mathrm{AQ}_{\text {ueous }}$ One Solution Reagent was added directly to culture wells. The plate was incubated at $37^{\circ} \mathrm{C}$ for $4 \mathrm{~h}$ in a humidified $5 \%$ $\mathrm{CO}_{2}$ atmosphere. The absorbance was recorded at $490 \mathrm{~nm}$ with a $96-$ well plate reader. Veh, vehicle; Pris, pristimerin.

(A)

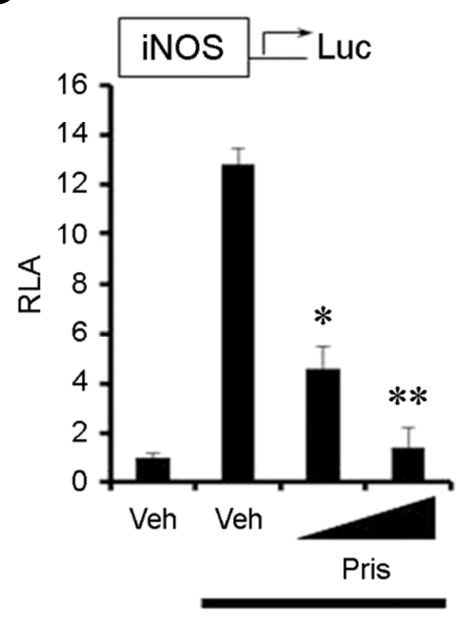

MALP-2
B

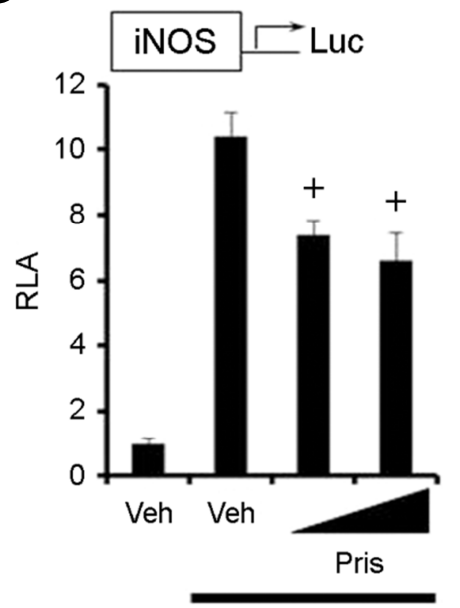

Poly[l:C]
C

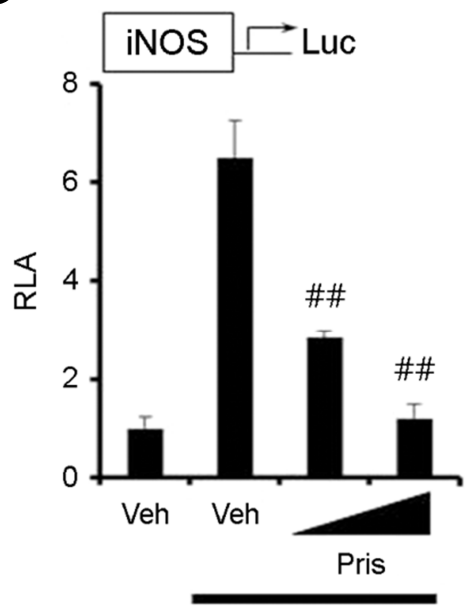

LPS

Fig. 2. (Pristimerin inhibits iNOS expression induced by TLRs agonists. (A-C) RAW264.7 cells were transfected with iNOS luciferase reporter plasmid and pretreated with 0.1 or $0.5 \mu \mathrm{M}$ pristimerin for $1 \mathrm{~h}$ and then treated with MALP-2 $(10 \mathrm{ng} / \mathrm{mL})(\mathrm{A}), \mathrm{Poly}[\mathrm{I}: \mathrm{C}](10 \mu \mathrm{g} / \mathrm{mL})$ (B), or LPS (10 ng/mL) (C) for an additional $8 \mathrm{~h}$. Cell lysates were prepared and luciferase enzyme activities were determined. Values represent the mean \pm SEM $(\mathrm{n}=3)$. *, Significantly different from MALP-2 alone, $P<0.05(*), P<0.01(* *)(\mathrm{A}) .+$, Significantly different from Poly[I:C] alone, $P<0.05$ (+) (B). \#, Significantly different from LPS alone, $P<0.01$ (\#\#) (C). Veh, vehicle; Pris, pristimerin.

\section{Nitrite Assay}

RAW264.7 세포로부터 nitrite 추출물을 선행연구 방법에 따라서 준비하였다(Lim et al., 2008). 세포 배양 well plate의 상층액에 분주기를 사용하여 Griess reagent를 첨가하였으 며, plate reader를 사용하여 $570 \mathrm{~nm}$ 에서 흡광도를 측정하였 다. 표준용액으로는 sodium nitrite를 사용하였다.

\section{데이타 분석}

각각의 데이타 값은 서로 다른 세 개의 값을 정량하여 얻어졌으며, mean \pm standard error mean (SEM)으로 표현되 었다. 


\section{결과 및 고찰}

\section{Pristimerin의 세포 독성 효과}

먼저 pristimerin이 RAW264.7 세포에 미치는 독성 효과 를 평가하기 위해 MTT assay를 사용하여 세포 생존율을 측정하였다. Pristimerin은 $0.5 \mu \mathrm{M}$ 의 농도에서 $96.0 \%, 1.0 \mu \mathrm{M}$ 농도에서 $90.0 \%$ 세포 생존율을 보여주었다(Fig. 1B). 따라 서 이후의 모든 실험은 prisitimerin을 $0.5 \mu \mathrm{M}$ 농도까지 사 용하여 수행하였다.

\section{Pristimerin은 TLR agonists에 의해 유도된 iNOS 발현 을 억제한다}

다음으로 pristimerin이 iNOS의 생성에 미치는 영향에
대하여 알아보았다. 먼저 iNOS-luciferase assay에 의하면 pristimerin은 MALP-2 (TLR2와 TLR6 agonist), Poly[I:C] (TLR3 agonist), 그리고 LPS (TLR4 agonist)에 의해 유도된 iNOS의 과발현을 억제하였다(Figs. 2A-C). 또한 Pristimerin 이 MALP-2, Poly[I:C], 그리고 LPS에 의해 유도된 iNOS 단백질의 과발현을 저해하는 것을 Western blotting 방법을 통하여 확인하였다(Figs. 3A-C). 뿐만 아니라 pristimerin은 MALP-2, Poly[I:C], 그리고 LPS에 의해서 유도된 iNOS의 생성물인 nitrite의 생성을 억제하였다(Figs. 4A-C). 이러한 결과들을 통해 pristimerin이 TLR agonists에 의해 증가하는 iNOS의 발현을 조절할 수 있음을 확인할 수 있었다.

Celastracease 식물로부터 추출된 pristimerin은 여러 가지 생물학적 효능을 가지고 있어 오랫동안 중국 전통 치료약 으로 사용되어 왔다. 여러 연구에 의하면 pristimerin은 염
(A)

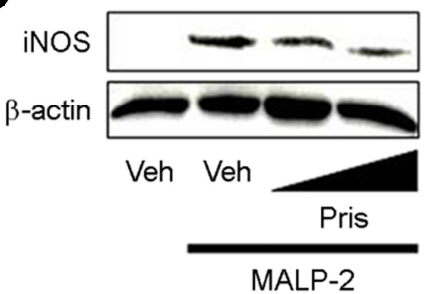

B

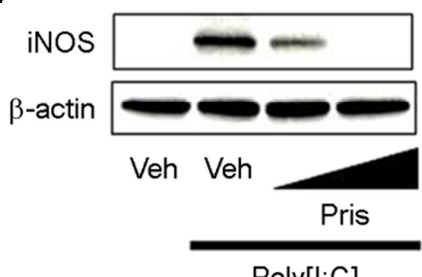

C

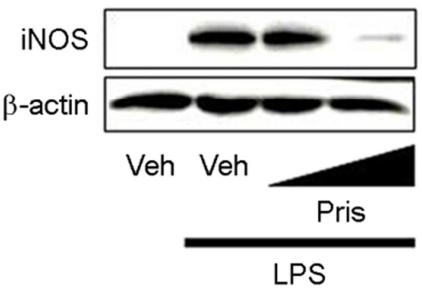

Fig. 3. Pristimerin inhibits iNOS protein induced by TLRs agonists. (A-C) RAW264.7 cells were pretreated with 0.1 or $0.5 \mu \mathrm{M}$ pristimerin for $1 \mathrm{~h}$ and then further stimulated with MALP-2 (10 ng/mL) (A), Poly[I:C $](10 \mu \mathrm{g} / \mathrm{mL})(B)$, or LPS (10 ng/mL) (C) for an additional $8 \mathrm{~h}$. Cell lysates were analyzed for iNOS and $\beta$-actin protein by immunoblots. Veh, vehicle; Pris, pristimerin.

A

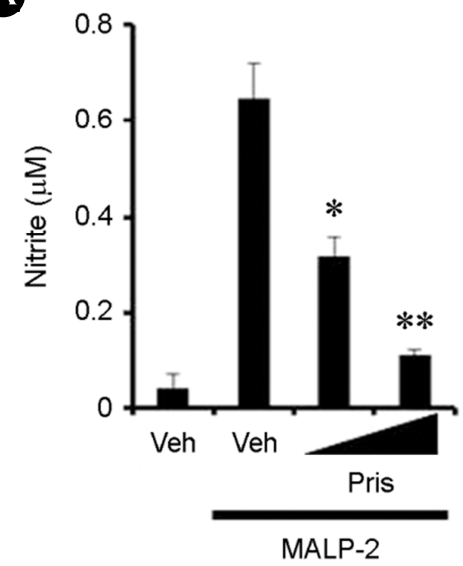

B

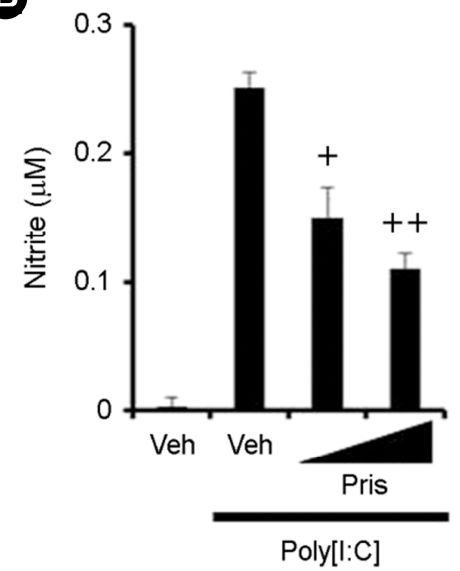

C

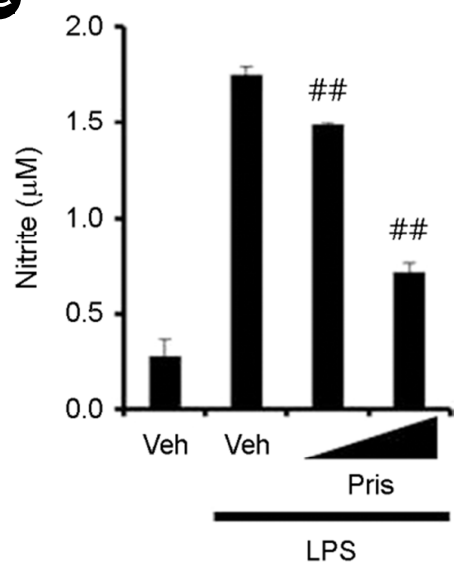

Fig. 4. Pristimerin inhibits nitrite production induced by TLRs agonists. (A-C) RAW 264.7 cells were pretreated with 0.1 or $0.5 \mu \mathrm{M}$ pristimerin for $1 \mathrm{~h}$ and then treated with MALP-2 $(10 \mathrm{ng} / \mathrm{mL})(\mathrm{A})$, Poly[I:C] $(10 \mu \mathrm{g} / \mathrm{mL})(\mathrm{B})$, or LPS $(10 \mathrm{ng} / \mathrm{mL})(\mathrm{C})$ for an additional $20 \mathrm{~h}$. The amounts of nitrite in supernatant were measured using Griess reagent. Values represent the mean \pm SEM $(n=3)$. *, Significantly different from MALP-2 alone, $P<0.05(*), P<0.01(* *)($ A). + , Significantly different from Poly[I:C $]$ alone, $P<0.05(+), P<0.01(++)$ (B). \#, Significantly different from LPS alone, $P<0.01$ (\#\#) (C). Veh, vehicle; Pris, pristimerin. 
증, 자가면역 및 종양과 같은 여러 질병에 효과적인 것으 로 알려져 있다(Costa et al., 2008; Deeb et al., 2014; Tong et al., 2014). 또한 pristimerin은 NF-kB나 그것의 염증 신호전달 시스템을 억제하는 것으로 알려져 있다(Deeb et al., 2014). 본 연구에서는 prisitmerin이 염증발현에 중요한 역할을 하 는 TLR 신호전달 시스템과 그것에 의해 조절되는 대표 적 단백질인 $\mathrm{iNOS}$ 의 발현을 억제하는 것을 처음으로 확 인하였다. 이러한 결과는 pristimerin이 만성염증 치료를 위한 항염증제로서 중요한 역할을 하는 것을 보여주었다.

TLRs는 일반적으로 MyD88과 TRIF에 의지한 신호전달 체계를 가지고 있다(Fitzgerald et al., 2003; Hultmark, 1994). $\mathrm{MyD} 88$ 은 TLR3를 제외한 모든 포유동물에서 발견되는 TLRs의 TIR (Toll/IL-1R) 도메인에 붙는 즉각적인 어댑터 (adaptor) 분자이며, 이것은 IL-1 receptor-associate kinase 4 (IRAK-4)를 유도한다. IRAK-4는 IRAK-1을 인산화 시켜 TNF receptor-associated factor 6 (TRAF6)를 유도하고, TRAF6 는 inhibitor of kappa B kinase (IאB kinase, IKK)를 활성화 시 켜 NF-KB의 활성화를 유도한다. 이렇게 TLRs를 시작으로 IKK kinases를 통해 NF-kB 활성화를 유도하는 신호전달 체계를 'canonical pathway'라고 부른다(Takeda and Akira, 2005). 이러한 신호전달 체계를 통해 cytokine, COX-2, iNOS 등의 염증 유전자 물질(inflammatory gene products) 들의 발현이 증가되어 다양한 질병을 유발하는 것으로 알 려져 있다(Takeda and Akira, 2005).

한편, 이중가닥 RNA (double stranded RNA, dsRNA)에 의한 TLR3 활성과 LPS에 의한 TLR4의 활성은 MyD88 대신에 어댑터 분자인 TRIF를 통하여 전사인자 IRF3의 활성화를 유도한다(Fitzgerald et al., 2003). 이 때 TRIF는 kinase인 TBK1과 IKKE을 통하여 IRF3의 인산화와 활성화 를 유도한다. 활성화된 IRF3는 IFN-stimulated response element (ISRE)나 regulated on activation normal T-cell Expressed and secreted (RANTES)로써 알려진 consensus DNA sequence에 결합하여 type I IFN 유전자들의 발현을 유도한 다. 또한 TRIF의 C-말단 부분은 receptor interacting protein 1 (RIP1)과 반응하여 지연된 NF-KB의 활성화를 유도한다 (Meylan et al., 2004). 따라서, TRIF는 TBK1과 RIP1을 통해 $\mathrm{IRF} 3$ 와 NF-kB 의 활성화를 유도하는 것으로 알려져 있다 (Sato et al., 2003).

병원균들이 숙주 안으로 들어오면 TLRs가 인식하여 신 호를 전달하고 연이은 여러 단백질들의 활성화를 통해 cytokine 등 염증 유전자 물질들의 발현이 증가한다. 이것 은 뒤이어 후천성 면역반응을 유도하여 다양한 질병으로
부터 숙주를 보호하는 것으로 알려져 있다. 하지만 계속 된 병원균의 자극에 의해 숙주의 면역시스템에 과부하가 걸리면 오히려 염증 유전자 물질들은 염증을 유발시켜 각 종 질병을 일으키게 된다. 그러므로, 병원균들에 의해 유 도된 TLRs의 신호전달 시스템의 활성을 억제하는 것은 이러한 시스템에 의한 만성염증과 같은 다양한 질병을 예 방하는 데 있어 매우 중요하다(Takeda and Akira, 2005).

우리는 본 연구에서 prisitmerin이 TLRs 자극제인 MALP2, Poly[I:C], 그리고 LPS에 의해 유도된 iNOS의 발현에 미치는 영향에 대해 확인하였다. Prisitmerin은 TLRs의 MyD88 신호전달 자극제인 MALP-2 (TLR2 and TLR6 agonist)와 TLRs의 TRIF 신호전달 자극제인 Poly[I:C] (TLR3 agonist)에 의해서 유도된 iNOS의 과발현을 각각 억제하 였다. 또한 prisitmerin은 TLRs의 MyD88과 TRIF의 양쪽 신호전달 자극제인 LPS (TLR4 agonist)에 의해 유도된 iNOS의 과발현을 저해하였다. 이러한 결과는 prisitmerin이 TLRs 신호전달 시스템을 조절하여 만성염증에 의해 유도 되는 여러 질병들을 치유할 수 있는 가능성을 보여준다. 따라서 본 연구의 결과는 다양한 만성 질환의 작용기전 규명 및 치료제 개발에 있어서 중요한 역할을 할 것으로 기대된다.

\section{ACKNOWLEDGEMENT}

본 연구는 순천향대학교 학술연구비의 일부 지원과 2017년도 한국연구재단의 지원을 받아 수행된 기초연구 사업(2017R1D1A1B03031534)의 지원을 받아 수행된 연구 결과물로 그 지원에 감사 드립니다.

\section{CONFLICT OF INTEREST}

No potential conflict of interest relevant to this article was reported.

\section{REFERENCES}

Akira S, Takeda K. Toll-like receptor signalling. Nat Rev Immunol. 2004. 4: 499-511.

Costa PM, Ferreira PM, Bolzani Vda S, Furlan M, de Freitas Formenton Macedo Dos Santos VA, Corsino J, de Moraes MO, Costa-Lotufo LV, Montenegro RC, Pessoa C. Antiproliferative activity of pristimerin isolated from Maytenus ilicifolia (Celastraceae) in human HL-60 cells. Toxicol In Vitro. 2008. 22: 854-863.

Deeb D, Gao X, Liu YB, Pindolia K, Gautam SC. Pristimerin, a 
quinonemethide triterpenoid, induces apoptosis in pancreatic cancer cells through the inhibition of pro-survival Akt/NFkappaB/mTOR signaling proteins and anti-apoptotic Bcl-2. Int J Oncol. 2014. 44: 1707-1715.

Ferrero-Miliani L, Nielsen OH, Andersen PS, Girardin SE. Chronic inflammation: importance of NOD2 and NALP3 in interleukin1beta generation. Clin Exp Immunol. 2007. 147: 227-235.

Fitzgerald KA, McWhirter SM, Faia KL, Rowe DC, Latz E, Golenbock DT, Coyle AJ, Liao SM, Maniatis T. IKKepsilon and TBK1 are essential components of the IRF3 signaling pathway. Nat Immunol. 2003. 4: 491-496.

Hultmark D. Macrophage differentiation marker MyD88 is a member of the Toll/IL-1 receptor family. Biochem Biophys Res Commun. 1994. 199: 144-146.

Kawai T, Akira S. The role of pattern-recognition receptors in innate immunity: update on Toll-like receptors. Nat Immunol. 2010. 11: 373-384.

Knowles RG. Nitric oxide synthases. Biochem Soc Trans. 1996. 24: 875-878.

Lechner M, Lirk P, Rieder J. Inducible nitric oxide synthase (iNOS) in tumor biology: the two sides of the same coin. Semin Cancer Biol. 2005. 15: 277-289.

Lim HJ, Lee HS, Ryu JH. Suppression of inducible nitric oxide synthase and cyclooxygenase-2 expression by tussilagone from Farfarae flos in BV-2 microglial cells. Arch Pharm Res. 2008. 31: 645-652.

Meylan E, Burns K, Hofmann K, Blancheteau V, Martinon F, Kelliher M, Tschopp J. RIP1 is an essential mediator of Tolllike receptor 3-induced NF-kappa B activation. Nat Immunol. 2004. 5: 503-507.

Murakami A, Ohigashi H. Targeting NOX, INOS and COX-2 in inflammatory cells: chemoprevention using food phytochemicals. Int J Cancer. 2007. 121: 2357-2363.

Sato S, Sugiyama M, Yamamoto M, Watanabe Y, Kawai T, Takeda $\mathrm{K}$, Akira S. Toll/IL-1 receptor domain-containing adaptor inducing IFN-beta (TRIF) associates with TNF receptor-associated factor 6 and TANK-binding kinase 1, and activates two distinct transcription factors, NF-kappa B and IFN-regulatory factor-3, in the Toll-like receptor signaling. J Immunol. 2003. 171: 4304 -4310 .

Takeda K, Akira S. Toll-like receptors in innate immunity. Int Immunol. 2005. 17: 1-14.

Tong L, Nanjundaiah SM, Venkatesha SH, Astry B, Yu H, Moudgil KD. Pristimerin, a naturally occurring triterpenoid, protects against autoimmune arthritis by modulating the cellular and soluble immune mediators of inflammation and tissue damage. Clin Immunol. 2014. 155: 220-230.

Vallance P. Nitric oxide: therapeutic opportunities. Fundam Clin Pharmacol. 2003. 17: 1-10.

Youn HS. The Anti-Inflammatory Effects of Phytochemicals by the Modulation of Innate Immunity. J Exp Biomed Sci. 2012. 18: 181-192.

Youn HS, Lee JY, Fitzgerald KA, Young HA, Akira S, Hwang DH. Specific inhibition of MyD88-independent signaling pathways of TLR3 and TLR4 by resveratrol: molecular targets are TBK1 and RIP1 in TRIF complex. J Immunol. 2005. 175: 3339-3346.

Youn HS, Lee JY, Saitoh SI, Miyake K, Hwang DH. Auranofin, as an anti-rheumatic gold compound, suppresses LPS-induced homodimerization of TLR4. Biochem Biophys Res Commun. 2006a. 350: 866-871.

Youn HS, Lee JY, Saitoh SI, Miyake K, Kang KW, Choi YJ, Hwang DH. Suppression of MyD88- and TRIF-dependent signaling pathways of Toll-like receptor by (-)-epigallocatechin-3-gallate, a polyphenol component of green tea. Biochem Pharmacol. 2006b. 72: 850-859.

Youn HS, Saitoh SI, Miyake K, Hwang DH. Inhibition of homodimerization of Toll-like receptor 4 by curcumin. Biochem Pharmacol. 2006c. 72: 62-69.

https://doi.org/10.15616/BSL.2019.25.1.60

Cite this article as: Kim SY, Heo SH, Park SA, Youn HS. Pristimerin Inhibits Inducible Nitric Oxide Synthase Expression Induced by TLR Agonists. Biomedical Science Letters. 2019. 25: 60-65. 